\title{
Hydrodemethoxylation/Dealkylation on Bifunctional Nanosized Zeolite Beta
}

\author{
Margarita Popova ${ }^{1, *}$, Ágnes Szegedi ${ }^{2}{ }^{\circ}$, Manuela Oykova ${ }^{1}$, Hristina Lazarova ${ }^{1}\left(\mathbb{D}\right.$, Neli Koseva $^{3}{ }^{(0}$, \\ Magdolna R. Mihályi ${ }^{2}$, Daniela Karashanova ${ }^{4}{ }^{\mathbb{D}}$, Yavor Mitrev ${ }^{1}$ and Pavletta Shestakova ${ }^{1}$
}

1 Institute of Organic Chemistry with Centre of Phytochemistry, Bulgarian Academy of Sciences, Acad. G. Bonchev Str., bl. 9, 1113 Sofia, Bulgaria; Manuela.Oykova@orgchm.bas.bg (M.O.); Hristina.Lazarova@orgchm.bas.bg (H.L.); Yavor.Mitrev@orgchm.bas.bg (Y.M.); Pavletta.Shestakova@orgchm.bas.bg (P.S.)

2 Research Centre for Natural Sciences, Institute of Materials and Environmental Chemistry, Magyar Tudosok krt. 2, 1117 Budapest, Hungary; szegedi.agnes@ttk.hu (Á.S.); mihalyi.magdolna@ttk.hu (M.R.M.)

3 Institute of Polymers, Bulgarian Academy of Sciences, Acad. G. Bonchev Str., bl. 103A, 1113 Sofia, Bulgaria; koseva@polymer.bas.bg

4 Institute of Optical Materials and Technologies, Bulgarian Academy of Sciences, Acad. G. Bonchev Str., bl. 109, 1113 Sofia, Bulgaria; dkarashanova@yahoo.com

* Correspondence: Margarita.Popova@orgchm.bas.bg

Citation: Popova, M.; Szegedi, Á.; Oykova, M.; Lazarova, H.; Koseva, N.; Mihályi, M.R.; Karashanova, D.; Mitrev, Y.; Shestakova, P. Hydrodemethoxylation/Dealkylation on Bifunctional Nanosized Zeolite Beta. Molecules 2021, 26, 7694. https:// doi.org/10.3390/molecules 26247694

Academic Editor: T. Jean Daou

Received: 20 November 2021 Accepted: 16 December 2021 Published: 20 December 2021

Publisher's Note: MDPI stays neutral with regard to jurisdictional claims in published maps and institutional affiliations.

Copyright: () 2021 by the authors. Licensee MDPI, Basel, Switzerland. This article is an open access article distributed under the terms and conditions of the Creative Commons Attribution (CC BY) license (https:// creativecommons.org/licenses/by/ $4.0 /)$.

\begin{abstract}
Mono-, and bimetallic Ni-, Ru-, and Pt-modified nanosized Beta zeolite catalysts were prepared by the post synthesis method and characterized by powder X-ray diffraction (XRD), nitrogen physisorption, HRTEM microscopy, temperature-programmed reduction (TPR-TGA), ATR FT-IR spectroscopy, and by solid-state MAS-NMR spectroscopy. The presence of nanosized nickel-oxide, ruthenium-oxide, and platinum species was detected on the catalysts. The presence of Brønsted and Lewis acid sites, and incorporation of nickel ions into zeolite lattice was proven by FT-IR of adsorbed pyridine. The structural changes in the catalyst matrix were investigated by solid state NMR spectroscopy. The catalysts were used in a gas-phase hydrodemethoxylation and dealkylation of 2-methoxy-4-propylphenol as a lignin derivative molecule for phenol synthesis.
\end{abstract}

Keywords: nanosized Beta zeolite; $\mathrm{Ni} / \mathrm{Ru} / \mathrm{Pt}$ catalysts; phenol synthesis; solid state NMR spectroscopy

\section{Introduction}

Due to the gradual increase in energy demand and the depletion of fossil carbon resources, the conversion of lignocellulosic biomass to fuels and chemicals has recently become the focus of research [1-5]. Lignocellulose is mainly composed of polymers of carbohydrates (cellulose and hemicellulose) and aromatics (lignin). Significant progress has been made in the production of value-added compounds from platform molecules obtained by acidic hydrolysis of cellulose and hemicellulose. However, valorization of lignin remains a major challenge due to the structural complexity and recalcitrance of the oxygenated p-propylphenol polymer [6]. The main lignin sources are the paper and pulp industry, as well as biorefineries producing bioethanol from cellulose. Despite of its emerging applications, such as emulsifier, binding agent, rheology modifier, carbon fiber precursor, etc., only $2 \%$ of lignin is commercialized. The rest is burned to produce cheap energy [7]. The depolymerization of lignin is the first step of its valorization, which leads to the formation of a complex mixture of phenolic compounds. The catalytic processes of selective demethoxylation and dealkylation leads to transformation of substituted phenols to phenol. Efficient dealkylation/demethoxylation of alkylphenols derived from lignocellulose was reported on bimetallic catalysts with metal active sites and Lewis and/or Brønsted sites $\left(\mathrm{Pt} / \gamma-\mathrm{Al}_{2} \mathrm{O}_{3}\right.$, Pt-, Ru- zeolite $\mathrm{ZSM}-5$, and ZSM-22, beta) [8-16]. The most efficient catalyst could selectively catalyze demethoxylation and de-alkylation processes and the mixture of 
substituted phenols will be converted into phenol. The phenol production is one of the most important industrial processes reaching an annual production of 8.9 million tons [17].

The application of nanosized bifunctional catalysts can improve the conversion of alkyl phenols and the selectivity to phenol production. Selection of metal species is of great importance for the demethoxylation and dealkylation processes. Noble metals, such as $\mathrm{Ru}$, $\mathrm{Rh}, \mathrm{Pd}$, and $\mathrm{Pt}$ are highly active for the dealkylation processes. Alternatively, less-costly metals such as $\mathrm{Ni}, \mathrm{Co}$, and Fe have been studied for bio-oil HDO. There are data presenting USY zeolite as a support, and they have demonstrated the benefit of USY supported transition metals on more than one bio-oil model compound. However, the micropores of the zeolite hinder the reactant access. The application of metals supported mesoporous acid zeolite catalysts could be a promising alternative to the conventional ones.

In this study, a nanosized zeolite Beta was modified with metals $(\mathrm{Ni} / \mathrm{Ru} / \mathrm{Pt})$ for the preparation of monometallic and bimetallic zeolite catalysts. The obtained catalysts were studied in the hydrodemethoxylation and dealkylation of 2-methoxy-4-propylphenol.

\section{Results and Discussion}

\subsection{Physico-Chemical Properties}

The pristine nanosized beta zeolite has peculiar textural properties. It is composed of 150-500 nm sized spherical particles, which are not single zeolite crystals, but agglomerated of 10-20 nm nanoparticles. Among the agglomerates there are mesopores, providing some hierarchical structure to the zeolite.

The crystalline phases of the zeolite Beta catalysts were identified by X-ray powder diffraction, and the results are shown in Figure 1. According to the patterns crystalline structure of the zeolite was preserved, and reflections characteristic for $\mathrm{RuO}_{2}$ and $\mathrm{NiO}$ nanoparticles on the external surface or among the voids of nanosized zeolite structure were found in the corresponding catalysts. Reflections of metallic platinum cannot be detected in Pt-containing preparations. It indicates that Pt particles that formed are quite small, below $5 \mathrm{~nm}$. Incorporation of ionic Pt species into the lattice ion-exchange positions also cannot be excluded [18]. The crystallite size of metal oxide particles was calculated by the Scherrer equation applying profile fitting method. It was found that $\mathrm{NiO}$ particles are with the size of $\sim 5 \mathrm{~nm}$ for $10 \mathrm{Ni} / \mathrm{HB}$ and $26 \mathrm{~nm}$ for $10 \mathrm{Ni} 1 \mathrm{Pt} / \mathrm{HB}$ (Table 1). The formation of ionic Pt species hinders the strong nickel interaction with the support leading to the formation of bigger $\mathrm{NiO}$ particles on $10 \mathrm{Ni} 1 \mathrm{Pt} / \mathrm{HB}$. Similar or somewhat smaller $\mathrm{RuO}_{2}$ particles $(26 \mathrm{~nm})$ are formed on the $5 \mathrm{Ru} / \mathrm{HB}$ sample then on the bimetallic $5 \mathrm{Ru} 1 \mathrm{Pt} / \mathrm{HB}$ $(29 \mathrm{~nm})$ one. This effect could be explained by the preparation procedure of bimetallic catalysts in which the modification with $\mathrm{Pt}$ is the first step followed by modification with $\mathrm{Ni}$ and $\mathrm{Ru}$ for $10 \mathrm{Ni} 1 \mathrm{Pt} / \mathrm{HB}$ and $5 \mathrm{Ru} 1 \mathrm{Pt} / \mathrm{HB}$, respectively. The succession of the modification procedure could benefit stronger interaction with Pt precursor with the unmodified surface of the initial Beta zeolite. The calculated size of the metal oxide particles is higher than the pore size of the support, which indicates that most of them are on the external surface of the zeolite. The high surface area and the nanosized morphology of zeolite particles predetermine the high dispersion of metal oxide nanoparticles on the modified catalysts.

The nitrogen adsorption/desorption isotherms of the initial Beta zeolite and its metalmodified varieties are shown in Figure 2. The calculated textural parameters are in Table 1. The isotherms are of type IV, typical for hierarchical zeolites, with some small hysteresis loop between $\mathrm{p} / \mathrm{p}_{0}=0.4-0.6$, characteristic for mesopores, probably in connection with the defected structure of the zeolite. By impregnation with noble and transition metals, somewhat decreased specific surface area and total pore volume can be observed (Table 1). It indicates that impregnating salts are penetrated the silica channels and the formed metal oxide nanoparticles are partly clogged them; occupation of ionic positions in zeolite lattice by metal cations is also a possible explanation. 


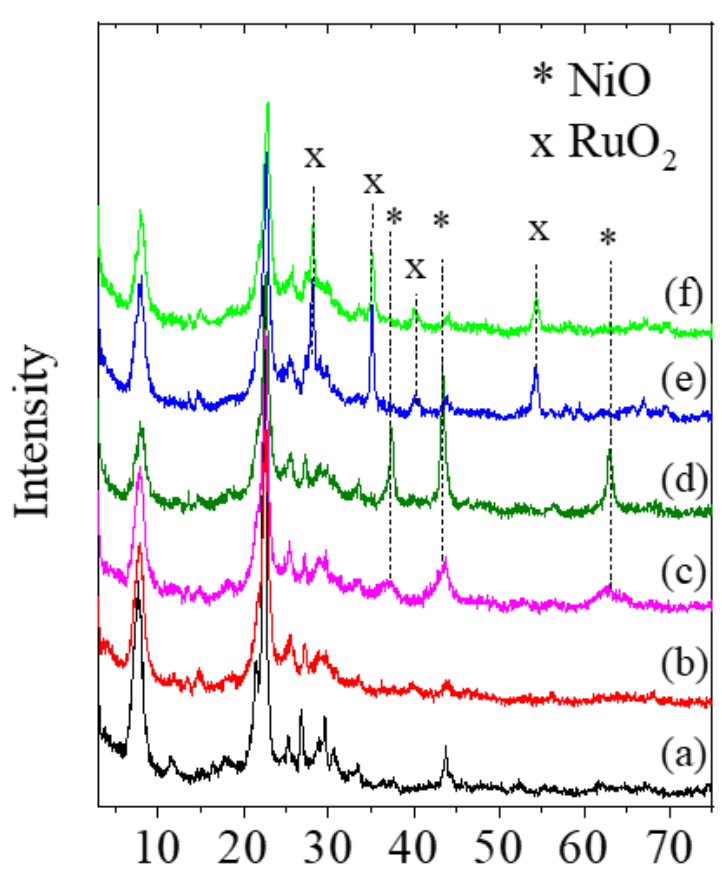

Bragg angle, ${ }^{\circ} 2 \theta$

Figure 1. X-ray powder diffraction patterns of the studied catalysts: (a) initial zeolite Beta, (b) $1 \mathrm{Pt} / \mathrm{HB}$, (c) $10 \mathrm{Ni} / \mathrm{HB},(\mathbf{d}) 10 \mathrm{Ni} 1 \mathrm{Pt} / \mathrm{HB},(\mathbf{e}) 5 \mathrm{Ru} / \mathrm{HB},(\mathbf{f}) 5 \mathrm{Ru} 1 \mathrm{Pt} / \mathrm{HB}$.

Table 1. Textural and other physico-chemical properties of the obtained catalysts.

\begin{tabular}{|c|c|c|c|c|}
\hline Samples & $\begin{array}{l}\text { BET Surface } \\
\text { Area, }\left(\mathrm{m}^{2} / \mathrm{g}\right)\end{array}$ & $\begin{array}{l}\text { Pore Volume, } \\
\left(\mathrm{cm}^{3} / \mathrm{g}\right)\end{array}$ & $\begin{array}{c}\text { Crystallite Size, } \\
(\mathrm{nm})\end{array}$ & $\begin{array}{c}\text { Reducibility }{ }^{\mathrm{a}}, \\
\text { (\%) }\end{array}$ \\
\hline Beta & 627 & 0.46 & - & - \\
\hline $10 \mathrm{Ni} / \mathrm{HB}$ & 577 & 0.34 & $5-\mathrm{NiO}$ & 90 \\
\hline $10 \mathrm{Ni1Pt} / \mathrm{HB}$ & 584 & 0.36 & $26-\mathrm{NiO}$ & $100(100)^{b}$ \\
\hline $1 \mathrm{Pt} / \mathrm{HB}$ & 604 & 0.42 & $<5$ & $100^{b}$ \\
\hline $5 \mathrm{Ru} / \mathrm{HB}$ & 579 & 0.36 & $26-\mathrm{RuO}_{2}$ & $96^{c}$ \\
\hline $5 \mathrm{Ru} 1 \mathrm{Pt} / \mathrm{HB}$ & 598 & 0.40 & $29-\mathrm{RuO}_{2}$ & $100(100)^{b}$ \\
\hline
\end{tabular}

a Calculated from TPR curve in the range of $150-600{ }^{\circ} \mathrm{C}$, based on the total weight loss related to the calculated theoretical weight loss for the reduction in the corresponding oxides to metallic state; ${ }^{\mathrm{b}}$ reducibility for $\mathrm{PtO}_{2}$; ${ }^{c}$ calculated from TPR2 curve after the TPR1-TPO-TPR2 experiments in the range of $150-600{ }^{\circ} \mathrm{C}$.

TPR-TG curves of the metal-containing mono- and bimetallic catalysts are displayed in Figure 3. TPR signal of 5Ru1Pt/HB sample shows the presence of one reduction peak below $200{ }^{\circ} \mathrm{C}$ in likewise the results of Gamliel et al. [19], with different intensities indicating the distinct reducibility of the metal oxide particles, $100 \%$ for $5 \mathrm{Ru} 1 \mathrm{Pt} / \mathrm{HB}$. The calculated extent of reduction in $\mathrm{RuO}_{2}$ particles in $5 \mathrm{Ru} / \mathrm{HB}$ is $63 \%$. However, our TEM results detected some metallic Ru particles. In order to calculate the real reducibility, we performed a consecutive temperature-programmed reduction 1 oxidation-reduction 2 (TPR1-TPO-TPR2) experiment. The calculated extent of reduction in the second TPR2 experiment corresponds to $96 \%$ (Table 1). We assume that the strong interaction of Pt with the support stabilizes the dispersion of $\mathrm{RuO}_{2}$ particles. In the TPR curves of nickel-containing samples intensive peaks centered at higher temperatures, between 335 and $505^{\circ} \mathrm{C}$ for $10 \mathrm{Ni} / \mathrm{HB}$ and a much lower one between 270 and $310{ }^{\circ} \mathrm{C}$ for $10 \mathrm{Ni1} \mathrm{Pt} / \mathrm{HB}$, can be distinguished. The lower temperature step most likely can be identified as a reduction in $\mathrm{NiO}$ particles, finely dispersed on the external surface of zeolite. Whereas the peak at elevated temperatures is associated with the more difficult reduction in ionic species situated in the zeolite lattice. The latter ones can be formed by ion-exchange during the wet impregnation procedure. In contrast to $10 \mathrm{Ni} 1 \mathrm{Pt} / \mathrm{HB}$ sample the reduction in $10 \mathrm{Ni} / \mathrm{HB}$ is incomplete up to $600{ }^{\circ} \mathrm{C}(90 \%)$, 
which fact also supports the formation of hardly reducible ionic Ni species in the zeolite lattice. It seems that the presence of platinum has advantageous effect on reducibility of $\mathrm{RuO}_{2}$ and $\mathrm{NiO}$ on zeolite Beta: the reducibility of Ru was increased, whereas nickel could be reduced at much lower temperature. Platinum is also reduced below $200{ }^{\circ} \mathrm{C}$ in this system, which suggest that $\mathrm{Pt}$ is in the form of easily reducible oxidic nanoparticles [20]. $\mathrm{Pt}$ in ion-exchange positions would be reducible over $250{ }^{\circ} \mathrm{C}$.

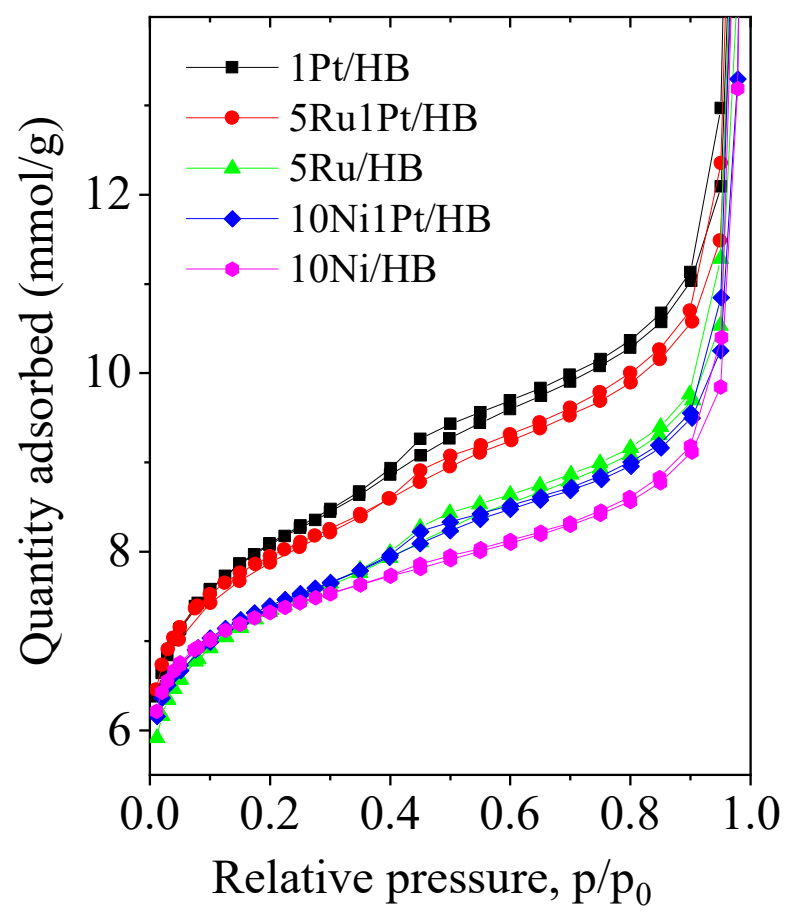

Figure 2. Nitrogen adsorption/desorption isotherms of $\mathrm{Ni}^{-}, \mathrm{Ru}-$, and Pt-modified $\mathrm{HB}$ zeolites.

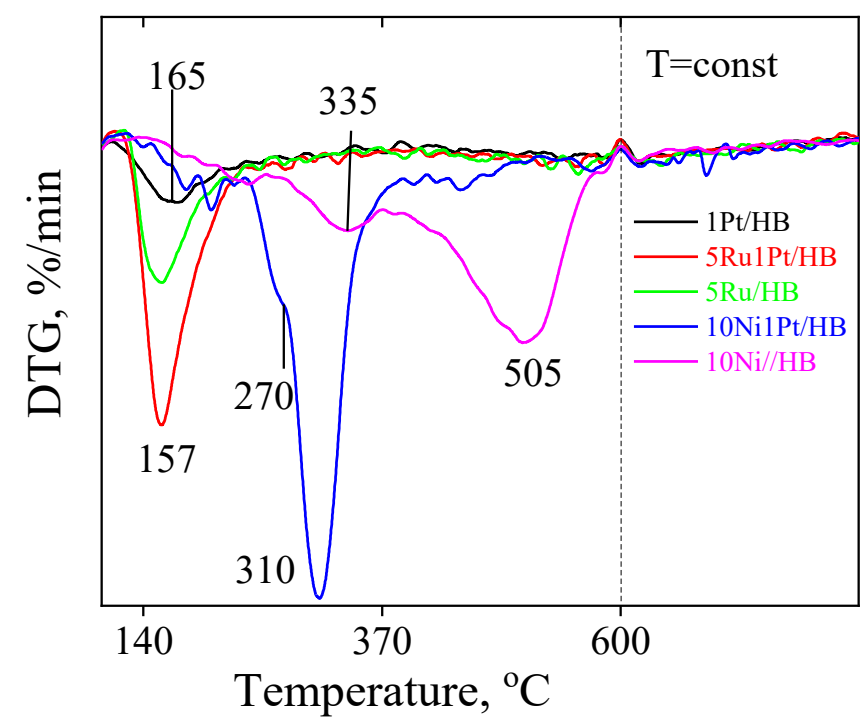

Figure 3. TPR profiles of the Ni-, Ru-, and Pt-modified nanosized Beta zeolites.

The band at $3735 \mathrm{~cm}^{-1}$ in the ATR FTIR spectrum [21] of the parent Beta zeolite is ascribed to the presence of internal $\mathrm{SiOH}$ groups (Figure S1). The shift of this band is registered for the modified zeolites and it is due to the strong interaction of the applied metals with the silanol groups of the support.

TEM micrographs and SAED patterns, as well as HRTEM images and the belonging FFT patterns of the initial and modified Beta zeolites are presented in Figure 4. A large-scale 
view at magnification of $10,000 \times$ of the aggregated particles is shown in Figure $4 a, d, g$, whereas images made at higher magnification (Figure $4 b, e, h$ ) demonstrate in more detail the shape and size of particles and the way of metal nanoparticle deposition on the zeolite surface. The zeolite particles are of elliptic shape and the sizes are between 100 and $200 \mathrm{~nm}$ for the longer diameter (Figure $4 \mathrm{~b}$ ). The metallic nanoparticles are rather spherical, and their size is below $10 \mathrm{~nm}$, as it is presented for Pt NPs in Ru-Pt sample (Figure 4i). These nanoparticles tend to coalesce, thus forming aggregates with irregular shapes, more expressed in the Ni-Pt sample (Figure 4e).
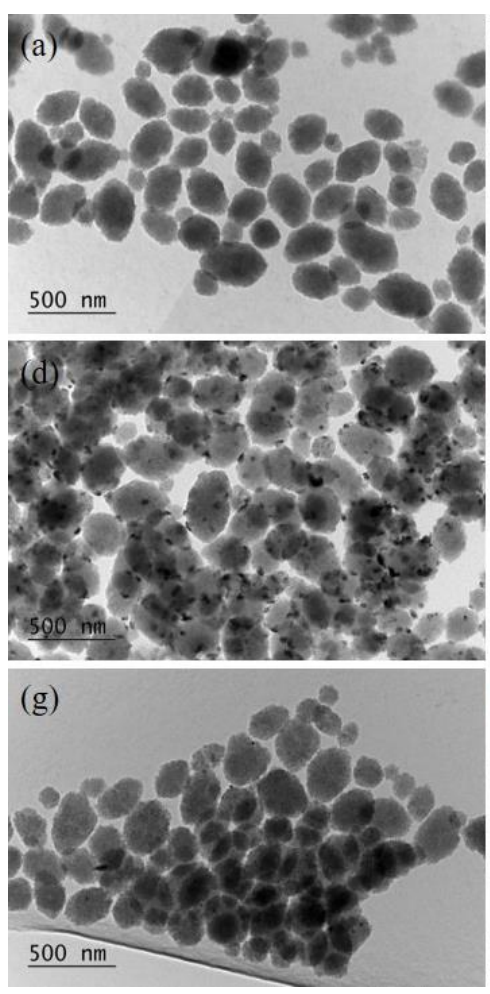
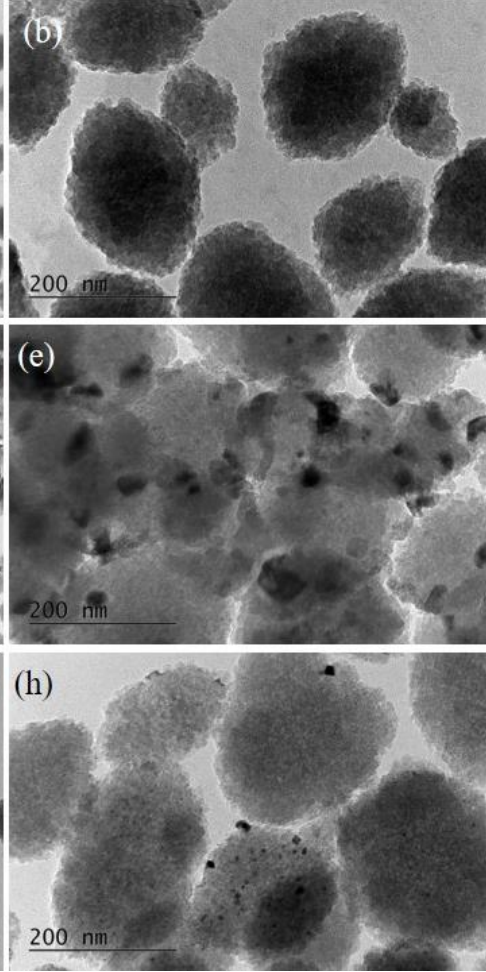
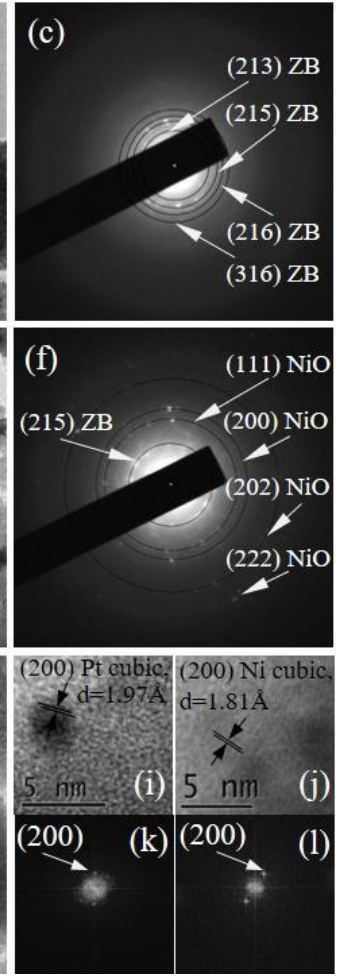

Figure 4. Bright Field TEM (BFTEM) images of zeolite Beta $(\mathbf{a}, \mathbf{b}), 10 \mathrm{Ni1Pt} / \mathrm{HB}(\mathbf{d}, \mathbf{e})$ and $5 \mathrm{Ru} 1 \mathrm{Pt} / \mathrm{HB}$ $(\mathbf{g}, \mathbf{h})$. SAED patterns of zeolite Beta (c) and 10Ni1Pt/HB (f). HRTEM images and the corresponding Fast Fourier Transform (FFT) patterns of 10Ni1Pt/HB (j, $\mathbf{l})$ and $5 \mathrm{Ru} 1 \mathrm{Pt} / \mathrm{HB}(\mathbf{i}, \mathbf{k})$ samples.

SAED analysis prove the presence of tetragonal beta zeolite (\# 91, database of the Zeolite Association), (Figure 4c) and cubic NiO (\# 96-101-0094, Crystallography Open Database, COD), (Figure 4f). These data are in accordance with the XRD results, but in addition HRTEM reveals the presence of cubic metallic Ni (\# 96-901-3035, COD), (Figure 4j,1) as well as cubic Pt (\# 96-101-1104, COD), (Figure 4i,k) phases in Ni-Pt and Ru-Pt samples, respectively. The metal nanoparticles deposition on the external surface which was assumed from XRD data is supported also by TEM measurements.

Additional information received by TEM analysis of the monometallic Ru sample is provided in Figure S2 in Supplementary materials. The TEM micrographs presented in Figure S2a,b reveal the morphology of the particles in the $5 \mathrm{Ru} / \mathrm{HB}$ sample. The zeolite particles with their ellipsoidal shape and weak electronic contrast, known from Figure 4a,b of the main paper, are well seen. The deposited on their surface, predominantly rod-like, well-faceted crystals with higher electronic contrast and sizes from 10 to $100 \mathrm{~nm}$ are also visualized. The HRTEM analysis proves that these well faceted particles represent $\mathrm{RuO}_{2}$ crystals, according the measured interplanar distance $\mathrm{d}=2.24 \AA$ between the lattice fringes in Figure S2e). This value coincides with the presented in Crystallography Open Database (COD), file \# 96-100-0059 for (200) family of planes of tetragonal $\mathrm{RuO}_{2}$. At the same time, second type of particles is found in this sample. Spherical-like and less than $10 \mathrm{~nm}$ in diameter, they are not visible in the micrographs at magnifications up to $40,000 \times$ because 
of their small sizes. The measured in Figure S2f interplanar distance for one particle of this type $d=2.21 \AA$ coincides well with the interplanar distance of (111) family of planes of metallic $\mathrm{Ru}$ (COD \# 96-153-4915). Additionally, ruthenium oxide is identified together with the zeolite phase in the sample $\mathrm{Ru} / \mathrm{HB}$ also by indexing the SAED pattern in Figure S2c, and the FFT pattern in Figure S2d, while the metallic Ru is proved also by the FFT pattern in Figure S2g.

The parent, and the $\mathrm{Ru}, \mathrm{Pt}$, and Ni modified $\mathrm{HB}$ zeolites were investigated by ${ }^{29} \mathrm{Si}$ and ${ }^{27} \mathrm{Al}$ NMR spectroscopy. The five different structural environments of the tetrahedrally coordinated $\mathrm{Si}$ atoms, denoted as $\mathrm{Si}(\mathrm{nAl})$, where $\mathrm{n}=0,1,2,3$, and 4 is the number of $\mathrm{Al}$ atoms sharing oxygen with the $\mathrm{SiO}_{4}$ unit, have characteristic chemical shifts in the ${ }^{29} \mathrm{Si}$ NMR spectra. In addition, the relative areas of the signals for the different $\mathrm{Si}(\mathrm{nAl})$ species reflect the composition of the zeolite framework. The single pulse ${ }^{29} \mathrm{Si}$ NMR spectra were quantitatively analyzed and the NMR signal areas of the different $\mathrm{Si}$ structural units were used to calculate the framework $\mathrm{Si} / \mathrm{Al}$ ratio according to following equation [19]:

$$
\mathrm{Si} / \mathrm{T}=\frac{\sum_{\mathrm{n}=0}^{4} \mathrm{I}_{\mathrm{Si}(\mathrm{nT})}}{\sum_{\mathrm{n}}^{4} 0.25 \mathrm{nI} \mathrm{I}_{\mathrm{Si}(\mathrm{nT})}}
$$

where $\mathrm{I}_{\mathrm{t}}$ is the total area of the spectrum and $\mathrm{I}_{\mathrm{Si}(\mathrm{nAl})}$ is the contribution of $\mathrm{Si}$ atoms with nAl neighbors in the second coordination sphere of the $\mathrm{SiO}_{4}$ units.

The single pulse ${ }^{29} \mathrm{Si}$ spectra and relative fractions of the different $\mathrm{Si}$ structures obtained by the deconvolution and fitting the spectra with the DMFit software are presented in Figure 5 and Table 2, respectively. The spectra of all materials showed five main resonances with chemical shifts centered at about $-101 \mathrm{ppm},-105 \mathrm{ppm},-107 \mathrm{ppm},-110 \mathrm{ppm}$, and $-114 \mathrm{ppm}$. The resonances at $-110 \mathrm{ppm}$ and $-114 \mathrm{ppm}$ are characteristic for $\mathrm{Si}(0 \mathrm{Al})$ species originating from two crystallographic tetrahedral $\mathrm{Si}(0 \mathrm{Al})$ sites. The signal at $-107 \mathrm{ppm}$ is typically assigned to $\mathrm{Si}(1 \mathrm{Al})$ units from $\left((\equiv \mathrm{Si}-\mathrm{O})_{3} \equiv \mathrm{Al}-(\mathrm{OH})-\mathrm{Si} \equiv\right)$ structural motifs with bridged hydroxyl groups. We suggest that the resonance at $-105 \mathrm{ppm}$ could be associated with $\mathrm{Si}(1 \mathrm{Al})$ species from defect framework sites where the $\mathrm{Si}$ atom is bound to tri-coordinated $\mathrm{Al}$ species. The resonance at $-102 \mathrm{ppm}$ indicates that some silanol groups $\mathrm{Si}(1 \mathrm{OH})$ are also present as defect sites in the zeolite matrix $[18,20,22]$. For the calculation of the $\mathrm{Si} / \mathrm{Al}$ ratio the total fraction of the $\mathrm{Si}(0 \mathrm{Al})$ total was considered as sum of the contributions of the $\mathrm{Si}(0 \mathrm{Al})$ resonances at $-110 \mathrm{ppm}$ and $-114 \mathrm{ppm}$, and the resonances for the $\mathrm{Si}(1 \mathrm{OH})$ at $-102 \mathrm{ppm}$. The framework $\mathrm{Si} / \mathrm{Al}$ ratio of 21 was determined for the parent $\mathrm{H}$-Beta zeolite. This ratio is higher as compared to the total $\mathrm{Si} / \mathrm{Al}$ ratio of 16 measured by ICP analysis, which could be explained by the fact that ICP measures both the FAl and $\mathrm{EFAl}$, while ${ }^{29} \mathrm{Si} \mathrm{NMR}$ does not take into account the aluminum originating from EFAl species. We assume that during the loading of metal, part of the EFAl species is introduced into the zeolite framework, and therefore the process of "healing" of zeolite framework occurs, resulting in decrease in the $\mathrm{Si} / \mathrm{Al}$ ratio. This suggestion is confirmed by the ${ }^{27} \mathrm{Al}$ NMR data (Figure 6) indicating that for all metal impregnated samples except $5 \mathrm{Ru} / \mathrm{HB}$, the fraction of FAl species increases while the fraction of the EFAl species is decreased (Table 2, last two columns). For the $5 \mathrm{Ru} / \mathrm{HB}$ sample, the $\mathrm{Si} / \mathrm{Al}$ ratio is still lower as compared to the parent sample, indicating that the "healing" process occurs; however; the ratio of EFAl to FAl species remains the same as for the parent zeolite. This apparent contradiction could be explained with distortion of the symmetry of the environment of some $\mathrm{Al}$ sites upon introduction of Ru. Previous studies demonstrated that in low symmetry environment the resonances of $\mathrm{Al}$ nuclei can be very broad and difficult to detect due to second-order interactions between the electric field gradient at the nucleus and the nuclear quadrupole moment of ${ }^{27} \mathrm{Al}$, resulting in fast relaxation of the $\mathrm{Al}$ nuclei. Therefore, we suggest that part of the signal originating from these distorted FAl sites (NMR "invisible" Al sites) is not fully detected, which gives lower apparent fraction for the FAl spices. The presence of distorted $\mathrm{Al}$ species is confirmed in the ${ }^{27} \mathrm{Al}$ spectrum by the observed broad low intensity 
hump in the region 35-50 ppm, partially overlapped with the main FAl resonance at around 60 ppm (Figure 6).
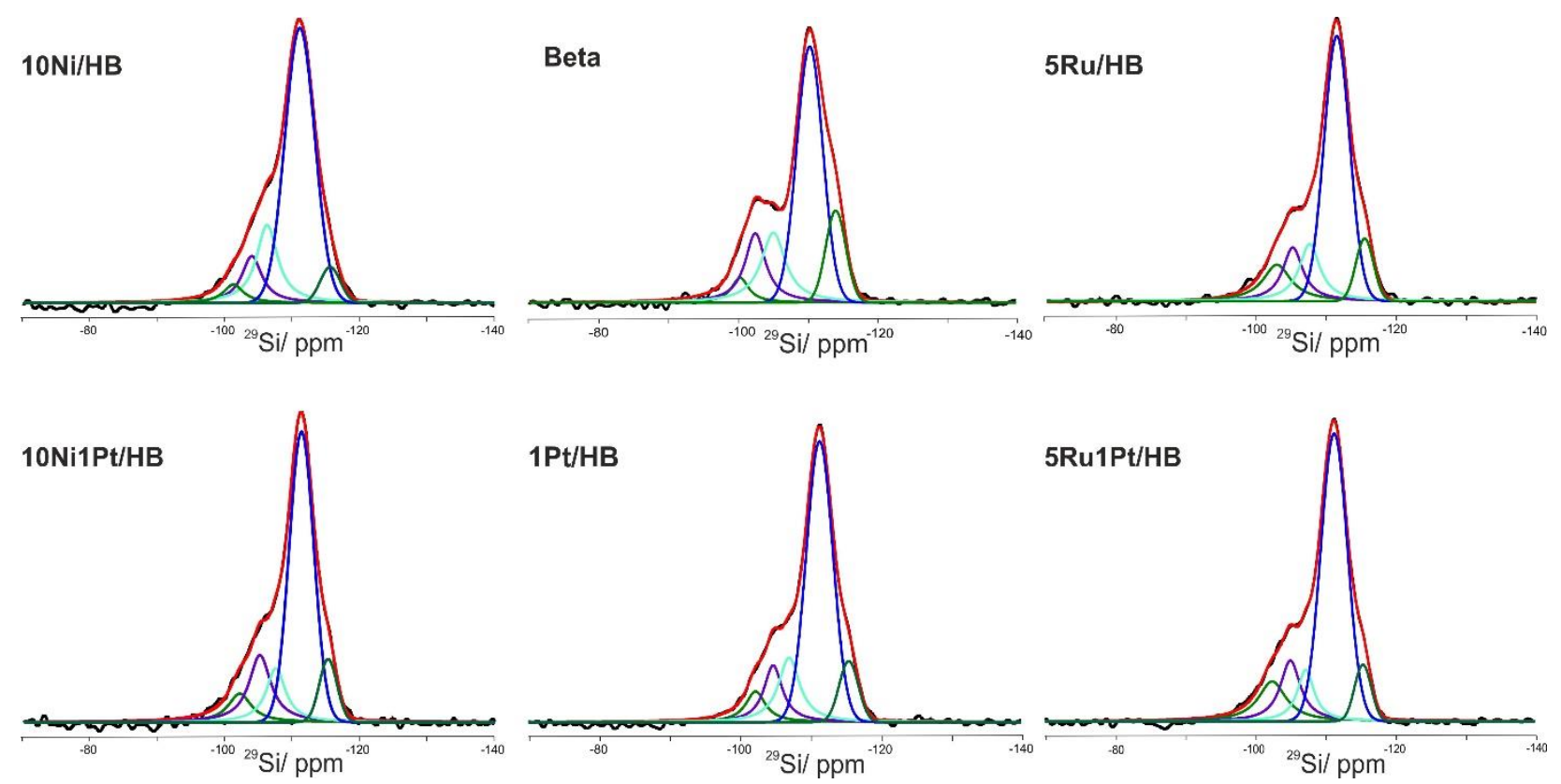

Figure 5. Experimental (black) and simulated (red) single-pulse ${ }^{29} \mathrm{Si}$ NMR spectra of the studied zeolites. The individual contributions of the different $\mathrm{Si}$ environments are given with colored lines.

Table 2. Area of the signals of the different Si structural units, obtained by deconvolution of the spectral patterns in the single pulse ${ }^{29} \mathrm{Si}$ NMR spectra, and the relative fractions of FAl and EFAl species, determined from 27Al NMR spectra.

\begin{tabular}{|c|c|c|c|c|c|c|c|c|}
\hline \multirow{2}{*}{ Sample } & \multirow{2}{*}{$\begin{array}{c}\text { Si(1OH) } \\
-101 \text { ppm }\end{array}$} & \multicolumn{2}{|c|}{ Si(1Al) } & \multicolumn{2}{|c|}{ Si(0Al) } & \multirow{2}{*}{$\mathrm{Si} / \mathrm{Al}$} & \multirow{2}{*}{ FAl, \% } & \multirow{2}{*}{ EFAl $\%$} \\
\hline & & -105 ppm & -107 ppm & $-110 \mathrm{ppm}$ & -114 ppm & & & \\
\hline Beta & $19 *$ & 19 & - & 49 & 13 & 21 & 80 & 20 \\
\hline $10 \mathrm{Ni} / \mathrm{HB}$ & 9 & 11 & 15 & 59 & 6 & 15 & 95 & 5 \\
\hline $10 \mathrm{Ni1Pt} / \mathrm{HB}$ & 14 & 17 & 10 & 52 & 7 & 15 & 86 & 14 \\
\hline $1 \mathrm{Pt} / \mathrm{HB}$ & 6 & 12 & 19 & 54 & 9 & 13 & 81 & 19 \\
\hline $5 \mathrm{Ru} / \mathrm{HB}$ & 12 & 13 & 15 & 52 & 9 & 14 & 80 & 20 \\
\hline 5Ru1Pt/HB & 15 & 12 & 10 & 55 & 7 & 18 & 83 & 17 \\
\hline
\end{tabular}

* The deconvoluted spectrum of parent zeolite Beta shows two resonances at $-100 \mathrm{ppm}$ and $-102 \mathrm{ppm}$ assigned for silanol groups with total relative area given in the table.
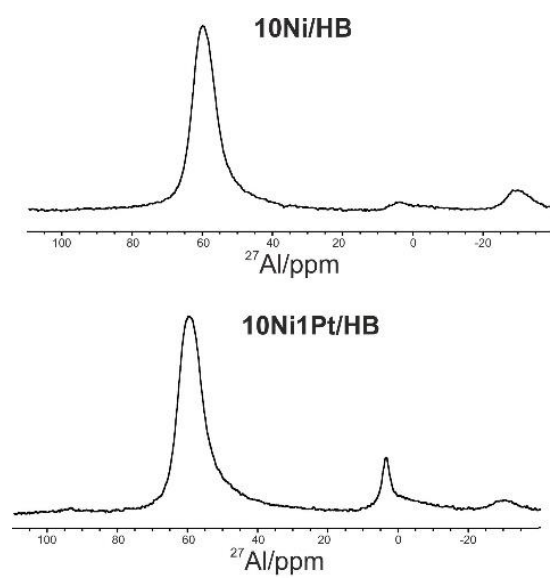
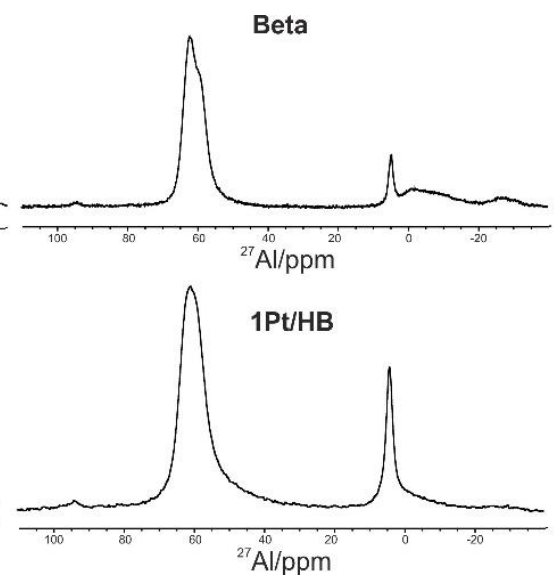

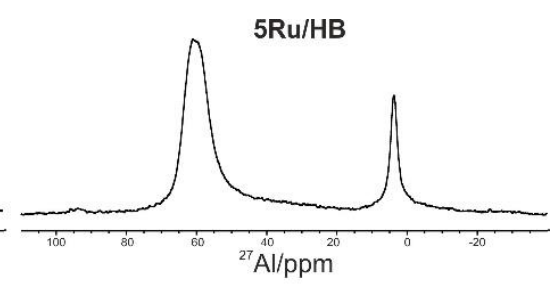

5 Ru1Pt/HB

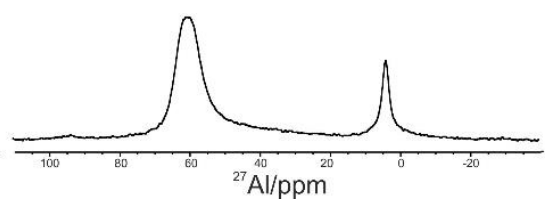

Figure 6. ${ }^{27} \mathrm{Al}$ NMR spectra of the studied zeolites. 
The ${ }^{29} \mathrm{Si}$ NMR spectra of mono- and bimetallic zeolite systems show the presence of the same type of Si structural units as in the parent Beta material, however with different quantitative distribution (Table 2). As a general trend the total fraction of the $\mathrm{Si}(0 \mathrm{Al})$ species (the resonances at -110 and $114 \mathrm{ppm}$ ) was similar to that in the parent Beta while the total amount of $\mathrm{Si}(1 \mathrm{Al})$ species was increased. A decrease in the $\mathrm{SiOH}$ groups resonance at -101 ppm was also detected.

The presence of $\mathrm{SiOH}$ groups was identified by the ${ }^{1} \mathrm{H} \rightarrow{ }^{29} \mathrm{Si} \mathrm{CP}$ MAS spectroscopy, which is based on transfer of polarization from sensitive spins $\left({ }^{1} \mathrm{H}\right)$ to nuclei with low sensitivity $\left({ }^{29} \mathrm{Si}\right)$ via through space dipole-dipolar interactions. Figure S3 shows as an example the ${ }^{1} \mathrm{H} \rightarrow{ }^{29} \mathrm{Si} \mathrm{CP}$ MAS spectra of Beta and $10 \mathrm{Ni} / \mathrm{BH}$ samples overlaid with their ${ }^{29} \mathrm{Si}$ single pulse spectra for comparison. In the ${ }^{1} \mathrm{H} \rightarrow{ }^{29} \mathrm{Si} \mathrm{CP}$ spectra of both samples the most enhanced resonance is at $-101 \mathrm{ppm}$, indicating the presence of silanol groups. The is also a slight enhancement of the $\mathrm{Si}(\mathrm{OAl})$ and the $\mathrm{Si}(1 \mathrm{Al})$ signals, due to possible magnetization transfer from the neighboring silanol protons, bridged hydroxyl protons, and/or coordinated water molecules. The enhancement of the $\mathrm{Si}(\mathrm{OAl})$ resonances is more pronounced in the parent Beta material while it could be considered as negligible in the10Ni/BH sample. Although the ${ }^{1} \mathrm{H} \rightarrow{ }^{29} \mathrm{Si} \mathrm{CP}$ spectra cannot be interpreted quantitatively, this result confirms that the number of $\mathrm{Si}-\mathrm{OH}$ groups in mono- and bimetallic zeolites is generally lower as compared to the parent material.

The coordination state of $\mathrm{Al}$ nuclei in the zeolite framework was investigated by ${ }^{27} \mathrm{Al}$ NMR (Figure 6). The parent Beta zeolite shows two partially overlapped resonances at -60 ppm that are characteristic for the tetracoordinated framework Al sites (FAl) with different symmetry. The presence of extra-framework Al species EFAl species represented by a narrow resonance at $\sim 4 \mathrm{ppm}$ and a broad higher field signal centered at $\sim-5 \mathrm{ppm}$. The simultaneous presence of FAl and EFAl was observed also by Majano et al. [23] when the same type of zeolite Beta was heat treated for template removal. Formation of octahedrally coordinated aluminum in hydrated samples can be explained also by coordination of water and/or silanol groups to tricoordinated aluminum atoms. The latter species can act as Lewis acid sites when dehydrated, and can be 'healed', i.e., converted to tetrahedral ones by dehydration or by incorporation of ammonia [24] or other metal cations into the lattice, as evidenced by our former study with silver ions [25].

The modification of parent Beta zeolite with $\mathrm{Ru}, \mathrm{Ni}$, and Pt results in some structural changes depending on the applied metals. The ${ }^{27} \mathrm{Al}$ spectra of all mono- and bimetallic zeolites display similar signals as parent $\mathrm{HB}$, except Ni modified ones. Different degrees of structural changes were observed as result of modification of parent Beta zeolite with $\mathrm{Ru}$, $\mathrm{Ni}$, and Pt. The ${ }^{27} \mathrm{Al}$ spectra of all mono- and bimetallic zeolites display similar signals as parent HB, except Ni modified ones. A broad resonance at around 40-38 ppm is mainly associated with additional structural transformations in the impregnated materials due to a distortion of the symmetry of the environment of some Al sites [23-29]. The fractions of FAl and EFAl species are given in the last two columns of Table 2. The parent HB catalyst has around $20 \%$ of EFAl sites, a huge part of it probably being hydrated tricoordinated aluminum, as evidenced by the significant intensity decrease in the 0 ppm signal by $\mathrm{Ni}$ impregnation (10Ni and $10 \mathrm{Ni1Pt} / \mathrm{HB}$ samples). The lowest content of the EFAl species was registered for $10 \mathrm{Ni} / \mathrm{HB}$ sample, which can be explained by the ion-exchange of nickel cations into the zeolite matrix during the impregnation process. Ni ions can be coordinated to trigonal aluminum and form tetrahedral sites. Ion-exchange with nickel ions was evidenced also by FT-IR spectroscopy of adsorbed pyridine (see below). The FAl/EFAl ratio in the other three samples $1 \mathrm{Pt} / \mathrm{HB}, 5 \mathrm{Ru} / \mathrm{HB}$, and $5 \mathrm{Ru} 1 \mathrm{Pt} / \mathrm{HB}$ was similar to those observed in the parent Beta material, indicating no ion exchange with $\mathrm{Ru}$ or $\mathrm{Pt}$.

Acidity of the catalysts can be investigated by FT-IR spectroscopy by adsorption of a base, such as pyridine (Py). The latter method can help to explore the Brønsted and Lewis acidic character of the catalysts [30]. Figure 7 represents the FT-IR spectra of the studied samples following Py adsorption. Ring vibrations $8 \mathrm{a}, 8 \mathrm{~b}$, and $19 \mathrm{~b}$ of Py give characteristic adsorption bands between 1700 and $1400 \mathrm{~cm}^{-1}$ [31]. Electron deficient surface Lewis acid 
sites (L-Py) interact with lone pairs of nitrogen in Py, or pyridinium ion is formed, when Brønsted acidic protons of zeolites (B-Py) reacts with Py. The band pair at 1545/1635 $\mathrm{cm}^{-1}$ is characteristic for B-Py sites, and L-Py bands can be found at 1445-55 and 1610-23 cm $\mathrm{cm}^{-1}$ values. Brønsted acidic sites are created in zeolites by balancing the negative framework charge of tetrahedrally coordinated $\mathrm{Al}(\mathrm{III})$ species with a proton, also known as bridged hydroxyl groups $\left((\equiv \mathrm{Si}-\mathrm{O})_{3} \equiv \mathrm{Al}-(\mathrm{OH})-\mathrm{Si} \equiv\right)$. Lewis acid bands are formed by interaction of Py with lattice cations like extra-framework $\mathrm{AlO}^{+}$or other metal ionic species. By Py adsorption one can get information about the amount of acid sites and their strength can be characterized by the temperature of desorption. In highly acidic zeolites Py is retained even at $400{ }^{\circ} \mathrm{C}$ by Brønsted and Lewis sites.
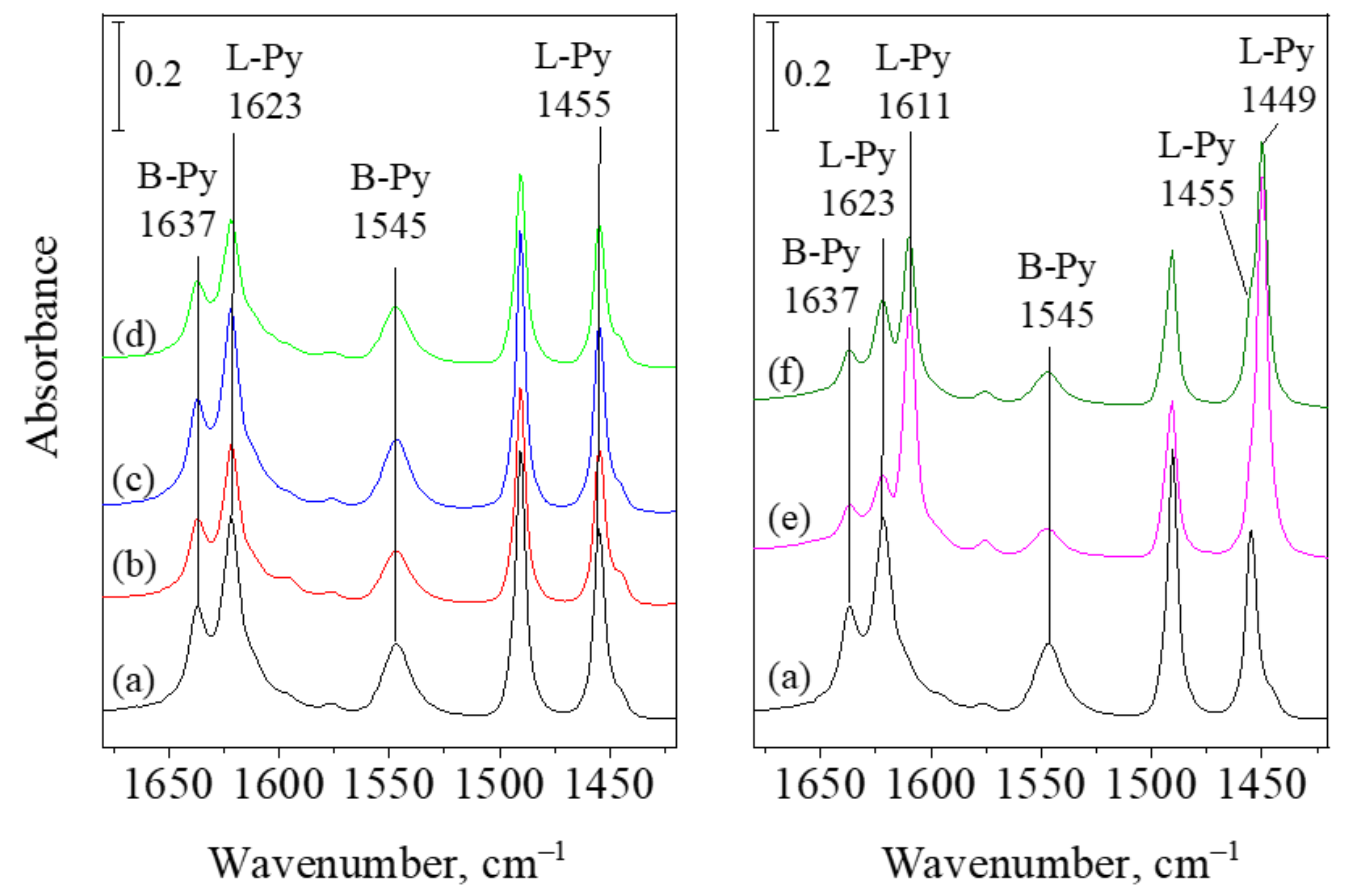

Figure 7. FT-IR spectra of adsorbed pyridine on the studied catalysts: (a) parent zeolite Beta, (b) $1 \mathrm{Pt} / \mathrm{HB}$ (c) $5 \mathrm{Ru} / \mathrm{HB}$, (d) $5 \mathrm{Ru} 1 \mathrm{Pt} / \mathrm{HB},(\mathbf{e}) 10 \mathrm{Ni} / \mathrm{HB}$, (f) $10 \mathrm{Ni} 1 \mathrm{Pt} / \mathrm{HB}$. Py (6 mbar) was adsorbed on $400{ }^{\circ} \mathrm{C}$ dehydrated samples at $200{ }^{\circ} \mathrm{C}$ and desorbed at $200{ }^{\circ} \mathrm{C}$ in high vacuum.

As formerly evidenced by NMR results, both Lewis and Brønsted type acid sites are detectable on HB (Figure 8a), however, compared to other zeolites, the Lewis acid centers are rather characteristic for defective structure of Beta than for extra framework $\mathrm{AlO}^{+}$ species. Thus, the $1455 / 1623 \mathrm{~cm}^{-1}$ band pair can be associated with Py coordinatively bound to tri-coordinated aluminum species in the defect sites of the zeolite.

Impregnation with noble metals slightly decreased the Brønsted acidity of the catalysts (Figure $7 \mathrm{~b}-\mathrm{d}$ ), most probably in association with some structure deterioration of the zeolite supported by XRD results. However, in the case of the nickel-containing samples (Figure 7e-f) decreased intensity of the L-Py bands and turn up of new, strong bands at $1449 / 1611 \mathrm{~cm}^{-1}$ proves some structural changes, namely, the presence of $\mathrm{Ni}^{2+}$ ions at cationic positions of the zeolite lattice. It seems that during the impregnation procedure ion exchange occurred. Nickel ions can replace the protons in bridged hydroxyl groups or can be connected to silanol groups neighboring the tri-coordinated aluminum species in the defect sites. The latter results in the 'healing' of the zeolite framework, i.e., changing of coordination of octahedral aluminum to tetrahedral, as supported also by ${ }^{27} \mathrm{Al}$ NMR results (Figure 6). The decreased intensity of $1545 \mathrm{~cm}^{-1}$ band shows that only about the one third of the original bridging hydroxyls remained by incorporation of nickel ions into the zeolite lattice. When $\mathrm{Ni}$ is impregnated on Pt-containing zeolite, the incorporation of nickel into cationic positions is incomplete, proved by the less intense $1450 / 1611 \mathrm{~cm}^{-1}$ 
Lewis bands, and more intense $1455 / 1623 \mathrm{~cm}^{-1}$ ones (Figure $8 \mathrm{e}$ ) compared to $10 \mathrm{Ni} / \mathrm{HB}$ catalyst. This observation is in line with XRD results, detecting higher amount of $\mathrm{NiO}$ on the external surface of platinum containing zeolite Beta, and by ${ }^{27} \mathrm{Al}$ NMR investigations shoving higher amount of octahedral aluminum species (Figure 6). Ni incorporation influenced not only the number of acid sites but also the strength of acidity, because Py was totally desorbed at $400{ }^{\circ} \mathrm{C}$ from the latter samples, in contrast to other studied catalysts (Figure $8 \mathrm{c}-\mathrm{d}$ ). Based on FT-IR spectroscopic method no evidence for entering of $\mathrm{Pt}$ or $\mathrm{Ru}$ ions into cationic positions could be found.

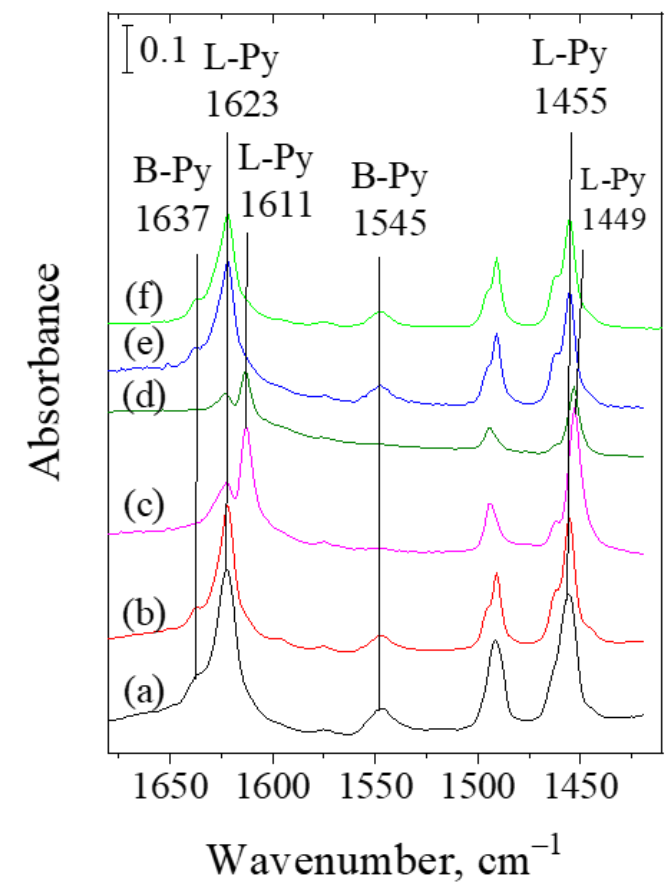

Figure 8. FT-IR spectra of adsorbed pyridine on the studied catalysts: (a) parent zeolite Beta, (b) $1 \mathrm{Pt} / \mathrm{HB},(\mathbf{c}) 10 \mathrm{Ni} / \mathrm{HB},(\mathbf{d}) 10 \mathrm{Ni} 1 \mathrm{Pt} / \mathrm{HB},(\mathbf{e}) 5 \mathrm{Ru} / \mathrm{HB},(\mathbf{f}) 5 \mathrm{Ru} 1 \mathrm{Pt} / \mathrm{HB}$. Py (6 mbar) was adsorbed on $400{ }^{\circ} \mathrm{C}$ dehydrated samples at $200^{\circ} \mathrm{C}$ and desorbed at $400{ }^{\circ} \mathrm{C}$ in high vacuum.

\subsection{Catalytic Activity for Phenol Preparation}

The prepared catalysts were investigated in hydrodemethoxylation and dealkylation of 2-methoxy-4-propylphenol. Demethoxylation of 2-methoxy-4-propylphenol leads to 4-propylphenol, followed by dealkylation to give phenol (Scheme 1). Liao et al. [32] showed that on zeolite beta in the presence of steam and in the absence of hydrogen and a metal component, not only dealkylation but isomerization, transalkylation and disproportionation of 4-propylphenol occur, especially at lower temperatures. The conversion of 2-methoxy-4-propylphenol and the selectivity to 4-propylphenol and phenol are compared at $300{ }^{\circ} \mathrm{C}$ for all catalysts (Figure 9). The isomerization, disproportionation and transalkylation of 4-propylphenol were negligible in the applied conditions.

2-methoxy-4-propylphenol conversion and phenol selectivity are higher on bimetallic catalysts than on monometallic catalysts (Figure 9A). Of the bimetallic catalysts, $5 \mathrm{Ru} 1 \mathrm{Pt} / \mathrm{HB}$ showed better catalytic performance. The presence of acidic and metallic centers is important for the transformations of 2-methoxy-4-propylphenol to phenol. Acidic and metallic centers of the catalysts play crucial role in transformation of 2-methoxy-4-propylphenol to phenol. Metal species selectively catalyze the hydrogenolysis of the methoxy group promoting the formation of 4-propylphenol. In addition, dealkylation of alkyl phenols to phenol proceeds on the acid sites (Scheme 1). $\mathrm{RuO}_{2}$ nanoparticles of $5 \mathrm{Ru} 1 \mathrm{Pt} / \mathrm{HB}$ catalyst showed higher reducibility, most probably owing to the interaction with platinum, resulting in the highest hydrogenolysis activity. It seems that the bimetallic $\mathrm{Ru}$ and $\mathrm{Pt}$ modification of zeolite HB led not only to higher activity but also to improved selectivity 
to phenol. This is explained by the peculiar properties of the zeolite-based catalysts, i.e., the combined effect of highly dispersed metallic species in the vicinity of strong acid sites as it was evidenced by XRD and FT-IR spectroscopic investigations. The incidence of both Brønsted and Lewis acid sites has beneficial effect on acidity of the zeolite enhancing the catalytic activity [31,33].<smiles>CCCc1ccc(O)c(OC)c1</smiles><smiles>CCCc1ccc(O)cc1</smiles><smiles>Oc1ccccc1</smiles>

Scheme 1. 2-Methoxy-4-propylphenol transformations on acid and metallic sites.
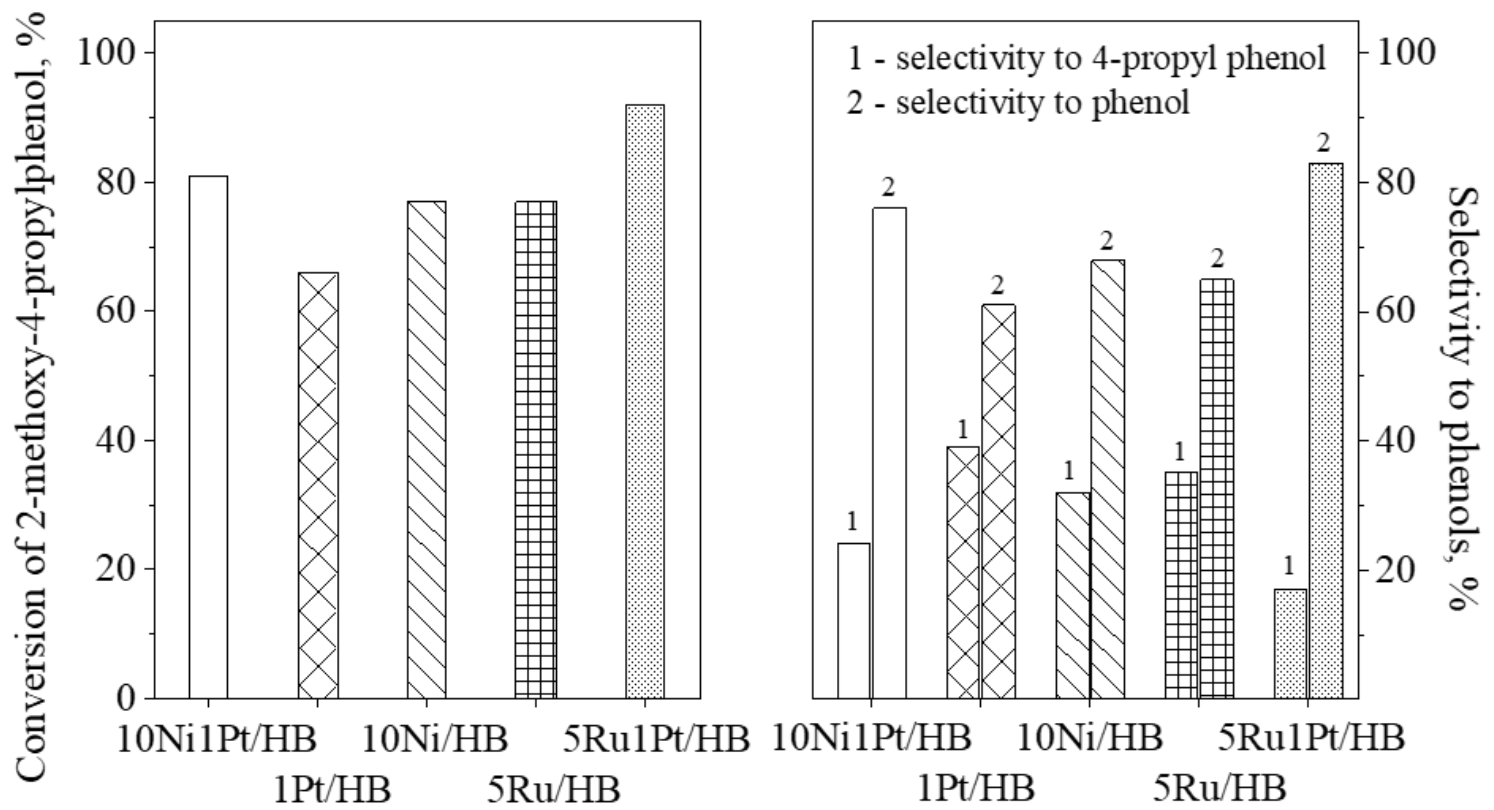

Figure 9. Catalytic activity of Ni-, Ru-, Pt-modified Beta zeolites in hydrodemethoxylation and dealkylation of 2-methoxy-4propylphenol at $300^{\circ} \mathrm{C}$.

The stability of the 5Ru1Pt/HB was tested in three reaction cycles and the data are presented in Figure 10. Catalyst deactivation due to coke formation is negligible. Improved diffusion of reactant and phenol products in beta nanoparticles reduces coke formation.

The XRD data of the spent catalysts do not show any presence of crystalline metal particles (Figure S4). In situ reduction in the metal oxides before the catalytic experiments leads to redistribution of the metal nanoparticles on the zeolite surface, not detectable by XRD. 

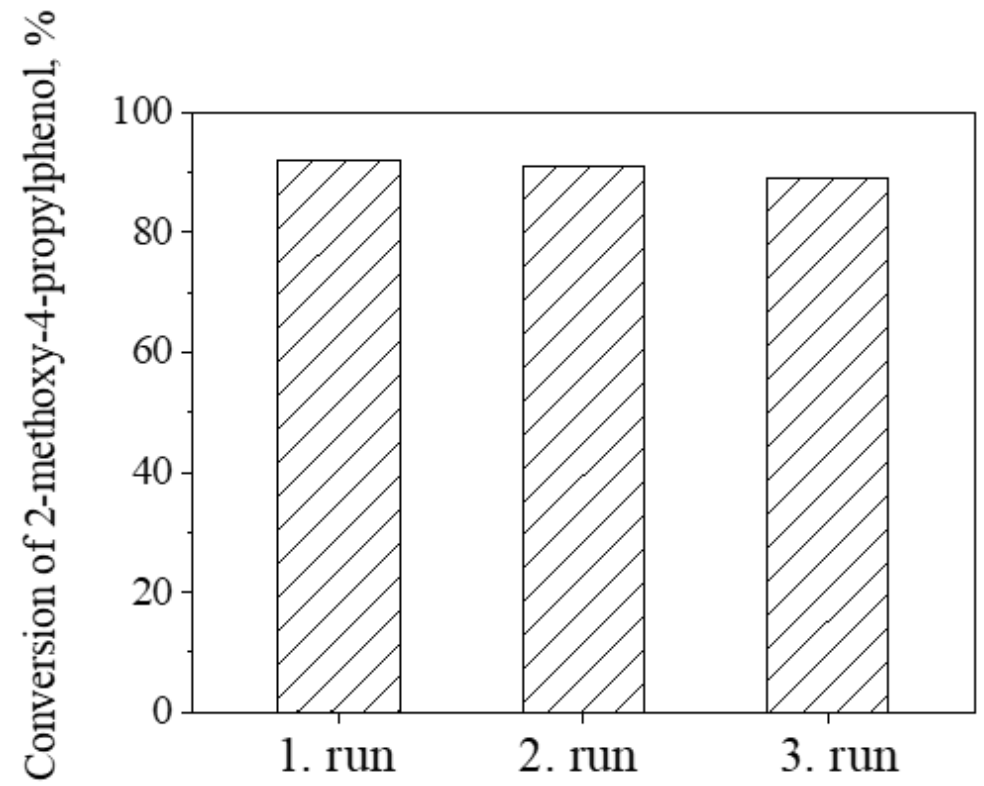

Figure 10. Catalytic activity of 5Ru1Pt-modified Beta zeolites in hydrodemethoxylation and dealkylation of 2-methoxy4-propylphenol at $300{ }^{\circ} \mathrm{C}$ in 3 reaction cycles.

\section{Experimental}

\subsection{Materials}

The reagents used for the preparation of zeolite Beta were sodium hydroxide $(\mathrm{NaOH}$, Sigma, St. Louis, MO, USA), aluminum isopropylate $\left(\mathrm{Al}\left(\mathrm{O}-\mathrm{CH}-\left(\mathrm{CH}_{3}\right)_{2}\right)_{3}\right.$, Sigma $), 30 \mathrm{wt}$ \% colloidal silica suspension (Bindzil 30/360 Akzo Nobel), tetraethylammonium hydroxide, 20 wt. \% aqueous solution (TEAOH, Sigma). All chemicals were used as received without any purification.

\subsection{Synthesis of Nanosized Beta Zeolite}

Zeolite Beta nanoparticles were synthesized according to Landau et al. [34]. In brief, the synthesis procedure includes the preparation of a precursor gel with the following molar composition: $25.00 \mathrm{SiO}_{2}: 0.25 \mathrm{Al}_{2} \mathrm{O}_{3}: 9.0 \mathrm{R}: 0.35 \mathrm{Na}_{2} \mathrm{O}: 295 \mathrm{H}_{2} \mathrm{O}$, where $\mathrm{R}$ is the organic templating agent tetraethylammonium hydroxide (TEAOH). The crystalline sample was recovered after 9 days of hydrothermal treatment of the gel at $100{ }^{\circ} \mathrm{C}$. The solid phase was washed and centrifuged with deionized water repeatedly until $\mathrm{pH} 7$ was reached then dried by freeze-drying. Organic structure-directing agent was removed by calcination at $550{ }^{\circ} \mathrm{C}$ for $6 \mathrm{~h}$ in static air to get the $\mathrm{H}$-form of the zeolite. The obtained zeolite contained $0.97 \mathrm{mmol} / \mathrm{g}_{\text {calc }} \mathrm{Al}$ and $0.07 \mathrm{mmol} / \mathrm{g}_{\text {calc }} \mathrm{Na}$, as determined by ICP-OES method by its microwave digesting in $\mathrm{HF} / \mathrm{HNO}_{3}$ mixture. The water content was $5.5 \mathrm{wt}$. \%. The bulk $\mathrm{Si} / \mathrm{Al}$ ratio was 16.3 , and the ion-exchange capacity is $0.83 \mathrm{mmol} / \mathrm{g}_{\text {calc }}$, determined by temperature-programmed evolution of ammonia from the $\mathrm{NH}_{4}$ form of zeolite Beta. The sample was denoted as HB.

\subsection{Impregnation with $\mathrm{Ni}, \mathrm{Ru}$, or/and Pt Nanoparticles of Nanosized Beta Zeolite}

Wet impregnation technique with nickel, ruthenium, and platinum salts was applied for loading of $10 \mathrm{wt}$. \%, $5 \mathrm{wt}$. \%, and $1 \mathrm{wt}$. \% metals, respectively (Scheme 2). The HB support was dehydrated at $160^{\circ} \mathrm{C}$ for $2 \mathrm{~h}$ before impregnation procedure. 


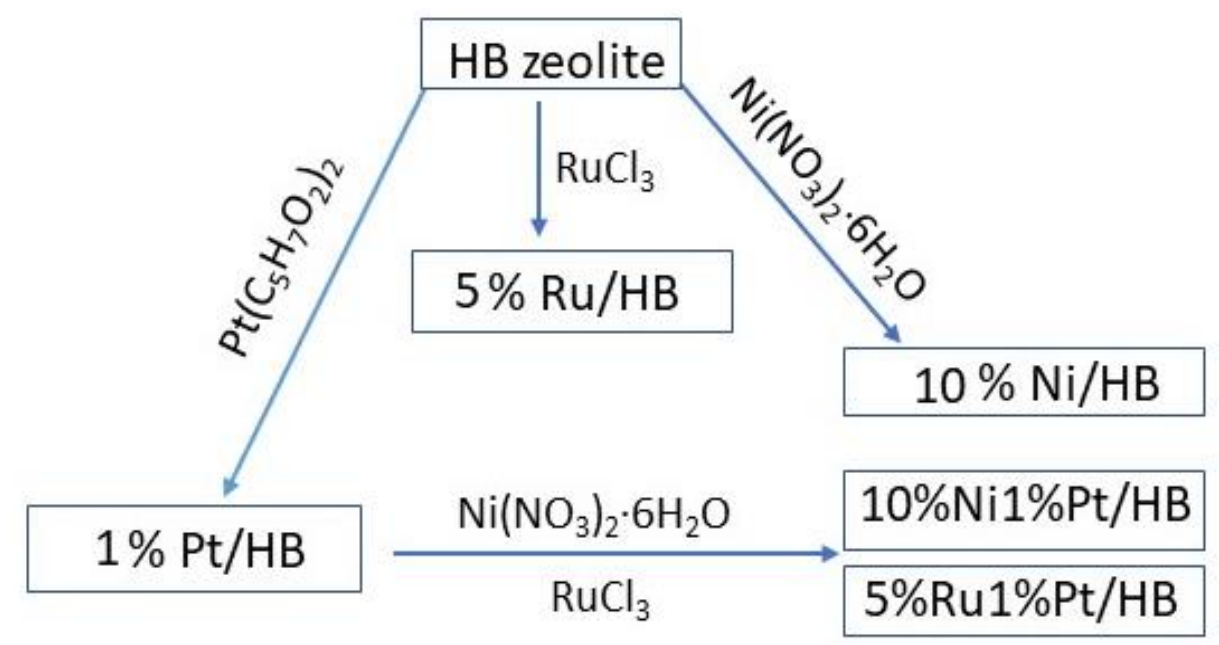

Scheme 2. Preparation of the catalysts.

Ni-modified Beta zeolite was prepared by the following procedure: $550 \mathrm{mg} \mathrm{Ni}\left(\mathrm{NO}_{3}\right)_{2} \cdot 6 \mathrm{H}_{2} \mathrm{O}$ was dissolved in $16.5 \mathrm{~mL}$ ethanol and was added to $1 \mathrm{~g} \mathrm{HB}$ support by stirring until evaporation of the solvent. Then the sample was dried at $80^{\circ} \mathrm{C}$ for $18 \mathrm{~h}$ and calcined at $450{ }^{\circ} \mathrm{C}$ for $3 \mathrm{~h}$ with a rate of $1^{\circ} \mathrm{C} / \mathrm{min}$. The sample was denoted as $10 \mathrm{Ni} / \mathrm{HB}$.

Pt-modified Beta zeolite was prepared by dissolving of $20 \mathrm{mg} \mathrm{Pt}(\mathrm{II})$ acetyl acetonate in $20 \mathrm{~mL}$ ethanol and then the solution was added to $1 \mathrm{~g} \mathrm{HB}$ support by stirring at room temperature for $1 \mathrm{~h}$. The ethanol solvent was removed in vacuum evaporator at $40{ }^{\circ} \mathrm{C}$. Then the sample was dried at $70^{\circ} \mathrm{C}$ for $18 \mathrm{~h}$ and calcined at $450{ }^{\circ} \mathrm{C}$ for $3 \mathrm{~h}$ with a rate of $1^{\circ} \mathrm{C} / \mathrm{min}$. The sample was denoted as $1 \mathrm{Pt} / \mathrm{HB}$.

Ru-modified HB sample was prepared by dissolving of $107 \mathrm{mg} \mathrm{RuCl}{ }_{3}$ in $80 \mathrm{~mL}$ water and then the solution was added to $1 \mathrm{~g}$ Beta zeolite by stirring at room temperature for $12 \mathrm{~h}$. The solvent was removed in vacuum evaporator at $40^{\circ} \mathrm{C}$. Then the sample was dried at $110^{\circ} \mathrm{C}$ for $12 \mathrm{~h}$ and calcined at $450{ }^{\circ} \mathrm{C}$ for $3 \mathrm{~h}$ with a rate of $1{ }^{\circ} \mathrm{C} / \mathrm{min}$. The sample was denoted as $5 \mathrm{Ru} / \mathrm{HB}$.

Bimetallic Pt- and Ni-modified Beta zeolite was prepared by the following procedure: $550 \mathrm{mg} \mathrm{Ni}\left(\mathrm{NO}_{3}\right)_{2} \cdot 6 \mathrm{H}_{2} \mathrm{O}$ dissolved in $46.6 \mathrm{~mL}$ ethanol was added to $1 \mathrm{~g} 1 \mathrm{Pt} / \mathrm{HB}$ sample and then was dried at $80^{\circ} \mathrm{C}$ for $18 \mathrm{~h}$. The precursor salt was decomposed in air at $450{ }^{\circ} \mathrm{C}$ with a rate of $1^{\circ} \mathrm{C} / \mathrm{min}$ for $3 \mathrm{~h}$. The sample was denoted as $10 \mathrm{Ni1Pt} / \mathrm{HB}$.

Bimetallic Ru- and Pt-modified HB sample was prepared dissolution of $109 \mathrm{mg} \mathrm{RuCl}$ in $16.5 \mathrm{~mL}$ water and was added to $1 \mathrm{~g} 1 \mathrm{Pt} / \mathrm{HB}$ sample and dried at $80^{\circ} \mathrm{C}$ for $18 \mathrm{~h}$. The precursor salt was decomposed in air at $450{ }^{\circ} \mathrm{C}$ with a rate of $1^{\circ} \mathrm{C} / \mathrm{min}$ for $3 \mathrm{~h}$. The sample was denoted as $5 \mathrm{Ru} 1 \mathrm{Pt} / \mathrm{HB}$.

\subsection{Characterization}

X-ray powder diffraction patterns were recorded by Philips PW 1810/3710 type (Bruker AXS Advanced X-ray Solutions $\mathrm{GmbH}$, Karlsruhe, Germany) diffractometer applying monochromatized $\mathrm{CuK}_{\alpha}$ radiation $(40 \mathrm{kV}, 35 \mathrm{~mA})$. Patterns were collected between 3 and $75^{\circ} 2 \theta$ with $0.02^{\circ}$ step size for $1 \mathrm{~s}$. Crystallite size of the metal oxides were determined by the Sherrer equation evaluating the FWMH values of the oxide phases with full profile fitting method. For the identification of crystalline phases ICDD database was used with card No. for zeolite Beta: 00-047-0183 $\mathrm{RuO}_{2}$ : 43-1027, NiO: 78-643.

Specific surface area and pore volume of the samples was determined from $\mathrm{N}_{2}$ physisorption isotherms collected at $-196{ }^{\circ} \mathrm{C}$ using AUTOSORB iQ-C-MP-AG-AG (Quantachrome Instruments, Anton Paar brand, Boynton Beach, FL, USA). Samples were pretreated at $350^{\circ} \mathrm{C}$ in vacuum before nitrogen adsorption. Total pore volume was determined according to the Gurvich rule at relative pressure of 0.9 .

The temperature-programmed reduction-thermogravimetric analysis (TPR-TGA) investigations were performed by a STA449F5 Jupiter type instrument of NETZSCH Geräte- 
bau GmbH (Netzsch, Germany). In a typical measurement $20 \mathrm{mg}$ of sample was placed in a microbalance crucible and heated in a flow of 5 vol. $\% \mathrm{H}_{2}$ in $\mathrm{Ar}\left(100 \mathrm{~cm}^{3} / \mathrm{min}\right)$ up to $500{ }^{\circ} \mathrm{C}$ at a rate of $5{ }^{\circ} \mathrm{C} / \mathrm{min}$ and a final hold-up of $1 \mathrm{~h}$. Prior to the TPR experiments the samples were treated in situ in at $500^{\circ} \mathrm{C}$ in air flow $\left(10^{\circ} \mathrm{C} / \mathrm{min}\right)$ for $1 \mathrm{~h}$.

TEM images were taken on JEOL JEM 2100 type transmission electron microscope (JEOL, Tokyo 196-8558, Japan) at $200 \mathrm{kV}$ accelerating voltage. Samples were suspended in a small amount of ethanol and a drop of the suspension was deposited onto a copper grid covered by amorphous carbon supporting film and dried at ambient conditions.

NMR spectra were recorded on a Bruker Avance II+ 600 NMR spectrometer (Bruker, Karlsruhe, Germany) operating at $600.01 \mathrm{MHz}{ }^{1} \mathrm{H}$ frequency $\left(119.21 \mathrm{MHz}\right.$ for ${ }^{29} \mathrm{Si}, 156.34 \mathrm{MHz}$ for $\left.{ }^{27} \mathrm{Al}\right)$, using $4 \mathrm{~mm}$ solid-state $\mathrm{CP} / \mathrm{MAS}$ dual ${ }^{1} \mathrm{H} /{ }^{31} \mathrm{P}-{ }^{15} \mathrm{~N}$ probehead. The samples were packed in $4 \mathrm{~mm}$ rotors $\left(\mathrm{Zr}_{2} \mathrm{O}\right)$ and spun at magic angle spinning (MAS) rate of $10 \mathrm{kHz}$ for the measurement of ${ }^{29} \mathrm{Si}$ spectra and at $14 \mathrm{kHz}$ for the ${ }^{27} \mathrm{Al}$ spectra. The quantitative ${ }^{29} \mathrm{Si}$ NMR spectra were acquired with single-pulse sequence, $90^{\circ}$ pulse length of $4.5 \mu \mathrm{s}$, time domain data points of $3 \mathrm{~K}$, spectrum width of $29 \mathrm{kHz}, 400$ transients were accumulated with a relaxation delay of $120 \mathrm{~s}$ between each scan. The spectra were zero filled to $16 \mathrm{~K}$ data points and processed with an exponential window function (line broadening factor 10) before the Fourier transformation. ${ }^{27} \mathrm{Al}$ spectra were acquired with single-pulse sequence, $90^{\circ}$ pulse length of $2.8 \mu \mathrm{s}, 128 \mathrm{~K}$ time domain data points, spectrum width of $780 \mathrm{kHz}$, 1024 scans, and a relaxation delay of $0.5 \mathrm{~s}$. All spectra were processed with an exponential window function (line broadening factor 10). The following experimental parameters were used for measuring the ${ }^{1} \mathrm{H} \rightarrow{ }^{29} \mathrm{Si}$ cross-polarization MAS (CP MAS) spectra: ${ }^{1} \mathrm{H}$ excitation pulse of $3.6 \mu \mathrm{s}$, contact time of $2 \mathrm{~ms}, 5 \mathrm{~s}$ relaxation delay, more than 4000 scans, MAS rate $10 \mathrm{kHz} .{ }^{1} \mathrm{H}$ SPINAL-64 decoupling scheme was used during acquisition of $\mathrm{CP}$ experiments.

FT-IR spectra were measured by a Nicolet Compact 6700 spectrometer (Thermo Fisher Scientific, Waltham, MA, USA). Self-supported wafers $(10 \times 20 \mathrm{~mm})$ were pressed and contacted with pyridine (Py, 6 mbar) as probe molecule. By placing the pellets into the special IR cell, samples were dehydrated at $400{ }^{\circ} \mathrm{C}$ in high vacuum for $1 \mathrm{~h}$. Py was adsorbed on substances for $30 \mathrm{~min}$ at $200{ }^{\circ} \mathrm{C}$, followed by subsequent evacuation at 100, 200, 300, and $400{ }^{\circ} \mathrm{C}$ for $30 \mathrm{~min}$. Py was desorbed at different temperatures by evacuation, and a spectrum was recorded at the IR beam temperature with 128 scans at a resolution of $2 \mathrm{~cm}^{-1}$. The spectra were normalized to $5 \mathrm{mg} / \mathrm{cm}^{2}$ weight of the wafers to make the quantitative comparison possible.

\subsection{Catalytic Activity Measurements}

Prior to the catalytic tests samples were pre-treated for $1 \mathrm{~h}$ in hydrogen $(60 \mathrm{~mL} / \mathrm{min})$ at $400{ }^{\circ} \mathrm{C}$. Hydrodemethoxylation of 2-methoxy-4-propylphenol was studied at atmospheric pressure using a fixed-bed flow-through reactor with $30 \mathrm{~mL} / \mathrm{min}$ hydrogen stream. In the reaction, the $50 \mathrm{mg}$ sample (particle size $0.2-0.8 \mathrm{~mm}$ ) was tested, and diluted with $50 \mathrm{mg}$ glass beads of the same diameter, previously checked to be inactive. The reactor itself was a quartz tube of $15 \mathrm{~mm}$ inner diameter, with the catalyst bed at the middle. A thermocouple was positioned in the catalyst bed for accurate measurement of the catalyst temperature. All gas lines of the apparatus were heated continuously at $110^{\circ} \mathrm{C}$ in order to minimize reactant and products adsorption on the tube walls. The gas stream passed through a saturator filled with 2-methoxy-4-propylphenol equilibrated at $80^{\circ} \mathrm{C}$. The reaction steady state was established after $30 \mathrm{~min}$ in each temperature. On-line analysis of the reaction products was performed using on NEXIS GC-2030 ATF (Shimadzu Group Company, Kyoto, Japan) with a $30 \mathrm{~m}$ HP 5MS capillary column. 


\section{Conclusions}

Mono- and bimetallic $\mathrm{Ni}$, Ru, and Pt-containing nanosized Beta zeolite catalysts were successfully prepared by impregnation procedure. Nanosized metal $(\mathrm{Ni}, \mathrm{Ru}$, and $\mathrm{Pt}$ ) particles were detected in the mono- and bimetallic catalysts. The incorporation of nickel ions into the zeolite matrix by the applied impregnation method was found. The obtained catalysts show high activity in hydrodemethoxylation/dealkylation of 2-methoxy-4ethylphenol to phenol. Among the studied catalysts, 5Ru1Pt/HB shows the highest activity, selectivity, and stability for formation of phenol by hydrodeoxygenation/dealkylation of 2-methoxy4-propylphenol obtained from lignin depolymerization.

Supplementary Materials: The following are available online, Figure S1 ART FTIR spectra of the initial and modified zeolites, Figure S2: Bright Field TEM (BFTEM) images of 5Ru/HB at magnification $10000 \times(\mathbf{a})$ and $40000 \times(\mathbf{b})$. SAED patterns (c), HRTEM images $(\mathbf{e}, \mathbf{f})$ and the corresponding Fast Fourier Transform (FFT) patterns (d, g) of 5Ru/HB sample, Figure S3. Comparison of the ${ }^{1} \mathrm{H} \rightarrow{ }^{29} \mathrm{Si}$ $\mathrm{CP}$ (black) and single pulse (red) ${ }^{29} \mathrm{Si} \mathrm{NMR}$ spectra of samples $10 \mathrm{Ni} / \mathrm{HB}$ and Beta. The lower signal-to-noise $(\mathrm{S} / \mathrm{N})$ ratio for the ${ }^{1} \mathrm{H} \rightarrow{ }^{29} \mathrm{Si} \mathrm{CP}$ spectra as compared to the single pulse experiments indicates the low efficiency of the magnetization transfer due to generally low amount of silanol groups present in the samples, Figure S4. XRD of the spent catalysts.

Author Contributions: M.P., conceptualization, supervision, writing—original draft, writingreview and editing, project administration; Á.S., investigation, writing — original draft, writingreview and editing; M.O. and H.L., investigation; Y.M., M.R.M., P.S., D.K. and N.K. investigation, writing - original draft. All authors have read and agreed to the published version of the manuscript.

Funding: This research was funded by European Regional Development Fund within the Operational Programme Science and Education for Smart Growth 2014-2020 under the Project Center of Excellence: National center of mechatronics and clean technologies-BG05M2OP001-1.001-0008.

Institutional Review Board Statement: Not applicable.

Informed Consent Statement: Not applicable.

Data Availability Statement: Not applicable.

Acknowledgments: M. Popova, H. Lazarova, and P. Shestakova thank for the financial support of the National Science Fund of Bulgaria, grant № KП-06-KOCT/3/2018. M. Popova, H. Lazarova, Neli Koseva, and P. Shestakova thank for the financial support the European Regional Development Fund within the Operational Programme Science and Education for Smart Growth 2014-2020 under the Project Center of Excellence: National center of mechatronics and clean technologiesBG05M2OP001-1.001-0008. M. Popova and M. Mihályi thank for the support of the COST Action CA17128: Establishment of a Pan-European Network on the Sustainable Valorisation of Lignin. The authors thank the Bulgarian Hungarian Inter-Academic Exchange Agreement for the support. M. Oykova acknowledges the partial support by the Bulgarian Ministry of Education and Science under the National Research Programme, "Young scientists and postdoctoral students" approved by DCM \# 577/17.08.2018. Á. Szegedi and M.R. Mihályi thank for the support provided by the Ministry of Innovation and Technology of Hungary from the National Research, Development, and Innovation Fund, financed under the 2019-2.1.13-TÉT_IN funding scheme (Project No. 2019-2.1.13-TÉT_IN-2020-00043). P. Shestakova and D. Karashanova thank the project Distributed Research Infrastructure INFRAMAT, part of Bulgarian National Roadmap for Research Infrastructures, supported by Bulgarian Ministry of Education and Science.

Conflicts of Interest: The authors declare no conflict of interest.

Sample Availability: Samples of Beta zeolites are available from the authors.

\section{References}

1. Huang, K.; Fasahati, P.; Maravelias, C.T. System-Level Analysis of Lignin Valorization in Lignocellulosic Biorefineries. iScience 2020, 23, 100751. [CrossRef]

2. Zhang, J.; Lombardo, L.; Gözaydın, G.; Dyson, P.J.; Yan, N. Single-step conversion of lignin monomers to phenol: Bridging the gap between lignin and high-value chemicals Chinese. J. Catal. 2018, 39, 1445-1452. [CrossRef] 
3. Romero, Y.; Richard, F.; Brunet, S. Hydrodeoxygenation of 2-ethylphenol as a model compound of bio-crude over sulfided Mo-based catalysts: Promoting effect and reaction mechanism. Appl. Catal. B Environ. 2010, 98, 213-223. [CrossRef]

4. Onwudili, J.A.; Williams, P.T. Catalytic depolymerization of alkali lignin in subcritical water: Influence of formic acid and Pd/C catalyst on the yields of liquid monomeric aromatic products. Green Chem. 2014, 16, 4740-4748. [CrossRef]

5. Shuai, L.; Amiri, M.T.; Questell-Santiago, Y.M.; Héroguel, F.; Li, Y.; Kim, H.; Meilan, R.; Chapple, C.; Ralph, J.; Luterbacher, J.S. Formaldehyde stabilization facilitates lignin monomer production during biomass depolymerisation. Science 2016, 354, 329-333. [CrossRef] [PubMed]

6. Sun, Z.; Fridrich, B.; de Santi, A.; Elangovan, S.; Barta, K. Bright Side of Lignin Depolymerization: Toward New Platform Chemicals. Chem. Rev. 2018, 118, 614-678. [CrossRef] [PubMed]

7. Schutyser, W.; Renders, T.; Van den Bosch, S.; Koelewijn, S.-F.; Beckham, G.T.; Sels, B.F. Chemicals from lignin: An interplay of lignocellulose fractionation, depolymerisation, and upgrading. Chem. Soc. Rev. 2018, 47, 852-908. [CrossRef] [PubMed]

8. Shao, Y.; Xia, Q.; Dong, L.; Liu, X.; Han, X.; Parker, S.F.; Cheng, Y.; Daemen, L.L.; Ramirez-Cuesta, A.J.; Yang, S.; et al. Selective production of arenes via direct lignin upgrading over a niobium-based catalyst. Nat. Commun. 2017, 8, 16104. [CrossRef]

9. Deuss, P.J.; Scott, M.; Tran, F.; Westwood, N.J.; de Vries, J.G.; Barta, K. Aromatic monomers by in situ conversion of reactive intermediates in the acid-catalyzed depolymerization of lignin. J. Am. Chem. Soc. 2015, 137, 7456-7467. [CrossRef] [PubMed]

10. Lancefield, C.S.; Ojo, O.S.; Tran, F.; Westwood, N.J. Isolation of Functionalized Phenolic Monomers through Selective Oxidation and C-O Bond Cleavage of the $\beta$-O-4 Linkages in Lignin. Angew. Chem. Int. Ed. 2015, 54, 258-262. [CrossRef]

11. Liao, Y.; d'Halluin, M.; Makshina, E.; Verboekend, D.; Sels, B.F. Shape selectivity vapor-phase conversion of lignin-derived 4-ethylphenol to phenol and ethylene over acidic aluminosilicates: Impact of acid properties and pore constraint. Appl. Catal. B Environ. 2018, 234, 117-129. [CrossRef]

12. Yoshikawa, T.; Umezawa, T.; Nakasaka, Y.; Masuda, T. Conversion of alkylphenol to phenol via transalkylation using zeolite catalysts. Catal. Today 2020, 347, 110-114. [CrossRef]

13. Verboekend, D.; Liao, Y.; Schutyser, W.; Sels, B.F. Alkylphenols to phenol and olefins by zeolite catalysis: A pathway to valorize raw and fossilized lignocellulose. Green Chem. 2016, 18, 297-306. [CrossRef]

14. Sun, J.; Karim, A.M.; Zhang, H.; Kovarik, L.; Li, X.S.; Hensley, A.J.; McEwen, J.-S.; Wang, Y. Carbon-supported bimetallic Pd-Fe catalysts for vapor-phase hydrodeoxygenation of guaiacol. J. Catal. 2013, 306, 47-57. [CrossRef]

15. Echeandia, S.; Pawelec, B.; Barrio, V.L.; Arias, P.L.; Cambra, J.F.; Loricera, C.V.; Fierro, J.L.G. Enhancement of phenol hydrodeoxygenation over Pd catalysts supported on mixed $\mathrm{HY}$ zeolite and $\mathrm{Al}_{2} \mathrm{O}_{3}$. An approach to O-removal from bio-oils. Fuel 2014, 117, 1061-1073. [CrossRef]

16. Ohta, H.; Feng, B.; Kobayashi, H.; Haraa, K.; Fukuoka, A. Selective hydrodeoxygenation of lignin-related 4-propylphenol into n-propylbenzene in water by $\mathrm{Pt}-\mathrm{Re} / \mathrm{ZrO}_{2}$ catalysts. Catal. Today 2014, 234, 139-144. [CrossRef]

17. Jung, K.B.; Lee, J.; Ha, J.M.; Lee, H.; Suh, D.J.; Jun, C.H.; Jae, J. Effective hydrodeoxygenation of lignin-derived phenols using bimetallic RuRe catalysts: Effect of carbon supports. Catal. Today 2018, 303, 191-199. [CrossRef]

18. Roldán, R.; Beale, A.M.; Sánchez-Sánchez, M.; Romero-Salguero, F.J.; Jiménez-Sanchidrián, C.; Gómez, J.P.; Sanka, G. Effect of the impregnation order on the nature of metal particles of bi-functional $\mathrm{Pt} / \mathrm{Pd}$-supported zeolite Beta materials and on their catalytic activity for the hydroisomerization of alkanes. J. Catal. 2008, 254, 12-26. [CrossRef]

19. Gamliela, D.P.; Karakalos, S.; Valla, J.A. Liquid phase hydrodeoxygenation of anisole, 4-ethylphenol and benzofuran using Ni, Ru and Pd supported on USY zeolite. Appl. Catal. A Gen. 2018, 559, 20-29. [CrossRef]

20. Wang, X.; Araia, M.; Wua, Q.; Zhang, C.; Zhao, F. Hydrodeoxygenation of lignin-derived phenolics-A review on the active sites of supported metal catalysts. Green Chem. 2020, 22, 8140-8168. [CrossRef]

21. Hao, W.; Zhang, W.; Guo, Z.; Ma, J.; Li, R. Mesoporous Beta Zeolite Catalysts for Benzylation of Naphthalene: Effect of Pore Structure and Acidity. Catalysts 2018, 8, 504. [CrossRef]

22. Montouillout, V.; Aiello, S.; Fayon, F.; Fernandez, C. Characterization of acid sites in dehydrated H-Beta zeolite by solid state NMR. Stud. Surf. Sci. Catal. 2002, 142, 383-390.

23. Engelhardt, G.; Lohse, U.; Lippmaa, E.; Tarmak, M.; Mägi, M.Z. ${ }^{29}$ Si NMR -Untersuchungen zur Verteilung der Silicium-und Aluminiumatome im Alumosilicatgitter von Zeolithen mit Faujasit-Struktur. Anorg. Allg. Chem. 1981, 482, 49-64. [CrossRef]

24. Majano, G.; Mintova, S.; Ovsitser, O.; Mihailova, B.; Bein, T. Zeolite Beta nanosized assemblies. Micropor. Mesopor. Mater. 2005, 80, 227-235. [CrossRef]

25. Kuehl, G.H.; Kyung, H.; Timken, C. Acid sites in zeolite Beta: Effects of ammonium exchange and steaming. Micropor. Mesopor. Mater. 2000, 35-36, 521-532. [CrossRef]

26. Shestakova, P.; Martineau, C.; Mavrodinova, V.; Popova, M. Solid state NMR characterization of zeolite beta based drug formulations containing Ag and sulfadiazine. RSC Adv. 2015, 5, 81957. [CrossRef]

27. Hunger, M. Solid-State NMR Spectroscopy. In Zeolite Characterization and Catalysis; Chester, A.W., Derouane, E.G., Eds.; Springer: Dordrecht, The Netherlands, 2009; Chapter 2; pp. 65-105.

28. Brunner, E.; Ernst, H.; Freude, D.; Frohlich, T.; Hunger, M.; Pfeifer, H. Magic Angle Spinning NMR Studies of Acid Sites in Zeolite H-ZSM-5. J. Catal. 1991, 127, 34-41. [CrossRef]

29. Van Bokhoven, J.A.; Koningsberger, D.C.; Kunkeler, P.; van Bekkum, H.; Kentgens, A.P.M. Stepwise Dealumination of Zeolite Beta at Specific T-Sites Observed with ${ }^{27} \mathrm{Al}$ MAS and ${ }^{27} \mathrm{Al}$ MQ MAS NMR. J. Am. Chem. Soc. 2000, 122, 12842-12847. [CrossRef] 
30. Akçay, M. The surface acidity and characterization of Fe-montmorillonite probed by in situ FT-IR spectroscopy of adsorbed pyridine. Appl. Catal. A Gen. 2005, 294, 156-160. [CrossRef]

31. Parry, E.P. An infrared Study of Pyridine Adsorbed on Acidic solids. Characterization of Surface Acidity. J. Catal. 1963, 2, 371-379. [CrossRef]

32. Liao, Y.; Zhong, R.; Makshina, E.; d'Halluin, M.; van Limbergen, Y.; Verboekend, D.; Sels, B.F. Propylphenol to Phenol and Propylene over Acidic Zeolites: Role of Shape Selectivity and Presence of Steam. ACS Catal. 2018, 8, 7861-7878. [CrossRef]

33. Bourgeat-Lami, E.; Massiani, P.; Di Renzo, F.; Espiau, P.; Fajula, F.; Des Courières, T. Study of the state of aluminium in zeolite- $\beta$. Appl. Catal. 1991, 72, 139-152. [CrossRef]

34. Landau, M.V.; Tavor, D.; Regev, O.; Kaliya, M.L.; Herskowitz, M.; Valtchev, V.; Mintova, S. Colloidal nanocrystals of zeolite $\beta$ stabilized in alumina matrix. Chem. Mater. 1999, 8, 2030-2037. [CrossRef] 